\title{
Formation of Emotional Intelligence of the Financial Company's Employees
}

\author{
E. G. Nikiforova ${ }^{1}$, D. S. Shakirova ${ }^{1}$ \& A. D. Abrosimova ${ }^{2}$ \\ ${ }^{1}$ Department of General Management, Institute of Management, Economics and Finance, Kazan Federal University, \\ Kazan, Russia \\ 2 The Institute of Management, Economics and Finance, Kazan Federal University, Kazan, Russia \\ Correspondence: D. S. Shakirova, Assistant, Department of General Management, Institute of Management, \\ Economics and Finance, Kazan Federal University, Kazan, Russia. Tel: 7-917-886-1557.
}

Received: August 1, 2020

doi:10.5430/ijfr.v11n5p485
Accepted: September 14, 2020

Online Published: October 5, 2020

URL: https://doi.org/10.5430/ijfr.v11n5p485

\begin{abstract}
Today human intelligence plays an important role in management activities. "Soft skills" are the basis for creating effective horizontal and vertical communications; however, for the effective management of employees today stands out another factor - management competencies, including emotional intelligence. Due to the ability to manage emotions, the employee is capable of self-motivation, to the effective management of conflict situations, work stress, and also increases the efficiency of staff. Accordingly, understanding the emotions of employees allows the financial company to analyze their actions and adjust them to create conditions that will satisfy the needs of the staff in exchange for meeting the needs of the organization if it is necessary. When considering the features of the formation of the emotional competence of employees, we found that emotional intelligence must be developed following the developed algorithm, especially leaders. The research also provides models for managing factors, as well as methods for assessing emotional competence and the mechanism for developing emotional intelligence on the example of retail trade (hypermarket with more than 300 employees) in Kazan.
\end{abstract}

Keywords: emotional intelligence, emotional competence, emotion management, soft skills

\section{Introduction}

First of all, it is necessary to define the concept of "emotional intelligence." This term was first proposed in 1985 by clinical physiologist R. Bar-On, who defined emotional intelligence as a set of cognitive abilities, competencies, and skills that affect a person's ability to cope with environmental challenges and pressures (Novukupova, I.N., Mehdiyev, S. Z. 2016). After which, in 1990, J. Mayer, P. Salovey, D. Caruso defined it as "the ability to identify the emotions and emotions of others and use this information to make decisions." That is, emotional intelligence as a model includes (Korolev, V.I., 2017):

- Ability to identify and express emotions (this allows you to use sources of non-verbal perception of information and empathy when interacting with people);

- Regulation of emotions (their own and strangers);

- The ability to use personal information in thinking and activity (includes skills in flexible planning, creative thinking, motivation).

Later, this model was finalized with a bias that emotions carry information about a person's connections with an object or other people. Based on this ability of emotional intelligence, they were described as a hierarchy consisting of (Korolev, V.I., 2017):

- Identification of emotions (perception of emotion, adequate expression and recognition of emotion imitations);

- Using emotions to increase the effectiveness of thinking and activity (using emotions to generate creative ideas or an analysis tool);

- Understanding of emotions (their connections, transitions, causes);

- Emotion management (control, intensity reduction, problem-solving without emotion suppression). 
As a competence, emotional intelligence is considered as a means of:

- Achieving company goals through the use of the energy of emotions. Emotions affect the motivation to achieve goals, as well as the perception of goals and their own belonging to the company due to internal feelings of security and comfort;

- Managing conflict situations by recognizing the cause of other people's emotions and the ability to influence them;

- Work with stress, which is associated with the manifestation of negative emotions such as fear, anxiety, anger. The suppression of these emotions leads to the accumulation of internal tension, which prevents a person from rationalizing his own and other people's actions. Their ecological expression, that is, the expression of these emotions without harm to people around them, contributes to the living of these emotions, which allows you to shift your focus of attention from them to other actions;

- Increasing efficiency due to a person's understanding of what factors cause negative emotions in him, and, as a result, stress, the ability to neutralize these factors.

The proliferation of research in the field of emotional intelligence has led to various interpretations of this concept, which were systematized by us in Table 1 .

Table 1. Approaches to the definition of emotional intelligence by different authors

\begin{tabular}{ll}
\hline Authors & Approaches to the definition of emotional intelligence \\
\hline R. Bar-On & $\begin{array}{l}\text { Emotional intelligence is a set of cognitive knowledge, abilities, and competencies that create a } \\
\text { person's opportunities for a meaningful life. } \\
\text { Components: self-knowledge, interpersonal skills, Adaptability, stress management, predominant } \\
\text { mood of happiness, and optimism (Goldberg C., 1991). }\end{array}$ \\
\hline P. Saloway & $\begin{array}{l}\text { Emotional intelligence was understood as "the ability to perceive and understand the manifestations } \\
\text { of the personality expressed in emotions, to control emotions based on intellectual processes } \\
\text { (Rogozhin, S.V., Rogozhina, T.V., 2002). }\end{array}$ \\
\hline D. Goleman & $\begin{array}{l}\text { Emotional intelligence is the ability to be aware of one's own emotions and the emotions of others } \\
\text { in order to motivate one and others and to manage emotions alone with oneself and in interactions } \\
\text { with others (Goleman D., 1988). }\end{array}$ \\
\hline I.N. Andreeva & $\begin{array}{l}\text { Emotional intelligence - self-actualization. } \\
\text { Natural emotional manifestation-positive self-wear and deep relationships with other people } \\
\text { (Andreeva, I.N., 2009). }\end{array}$ \\
\hline D.V. Lucin & $\begin{array}{l}\text { Emotional intelligence is a collection of abilities for understanding and managing yours and others' } \\
\text { emotions. Components: interest in the inner world of people, the tendency to the psychological } \\
\text { analysis of behavior (Anokhin, P.K. Emotions. Psychology of emotions. Texts, 1984). }\end{array}$ \\
\hline
\end{tabular}

Source: self-made.

By analyzing these definitions, we can distinguish the following essential elements of emotional intelligence:

- understanding the nature of emotions, their causal relationships;

- analysis and interpretation of emotions as an additional source of information;

- managing your emotions and other people's emotions to increase the effectiveness of interaction between people.

\section{Development}

\subsection{Emotional Intelligence as a Factor in Improving the Quality of Management}

Consider the use of emotional intelligence as a critical factor in increasing the effectiveness of organization management.

In the scientific literature, one can find the concept of "human factor," which is considered both the factor of success of decisions made and the key reason for errors in the actions of organizations. At the same time, it is the basis of management, which consists in the knowledge of the management subject of his business, the ability to organize his work and the work of the group, in interest in self-development and creative activity (Bereznyak, G.A., Martynov, Yu, 


\section{I., Salikov, Yu. A., 2016).}

The rationality of decision making is related to the ability to manage your emotions. Moreover, they are opposed to each other. When the human factor is mentioned as a source of error, then emotions are considered as a key factor that had a negative impact on the quality of decisions. To explain this factor and the ability to manage it, the idea of developing "emotional intelligence" in employees is widespread in management today (Naseri \& Moradi, 2016).

K. Stampf, V. Wundt, L.M. Wecker explain the phenomenon of emotions as a reflection of a person's attitude to phenomena (Vekker, L. M., 1998). Information about a person's attitude to a phenomenon allows predicting the possible behavior of personnel (in particular, negative), which is associated with specific actions of organizations or the introduction of innovations.

Anokhin, P. K. (1984) in biological theory, noted that emotion integrates all body functions in order to achieve biologically beneficial results and satisfy needs. The satisfaction of needs, according to A. Maslow's theory, occurs in a certain sequence. And the failure to satisfy the needs of the emotions of one level leads to the impossibility of satisfying the emotions of the next level. Because an organization can contribute to meeting the needs of its people, it expects that ultimately meeting the needs (achieving goals, achieving objectives, growing and developing) of the organization will be the next step. And to increase this likelihood, the organization seeks to help meet the needs of its employees. Accordingly, emotional intelligence contributes to a more transparent determination of the needs of personnel, both by management and by the personnel themselves.

Within the framework of studying this topic, it is especially important to consider the psychodynamic approach (R. Holt, D. Rapaport, Z. Freud, G. Klein) (Izard, KA, 2000), which says that affect, that is, emotion is a motivational variable ... And the ability to work with your emotions to evoke positive emotions speaks of the ability to self-motivation, which is an independent motivation of a person to achieve the goals of the organization.

Within the framework of the modern approach, the primary function of emotions is the motivation to action (Barrett, Campos, Izard, etc.). They are also key components of cognitive processes, social behavior, and physical health. According to the authors' conclusions, for successful work activity, a person should establish control over his emotions and learn to express them by generally accepted rules of behavior in society (Korolev, V.I., 2017).

Accordingly, understanding the emotions of employees allows the company to analyze its actions and correct them if necessary, to create conditions that will satisfy the needs of the staff in exchange for meeting the needs of the organization.

A high level of emotional intelligence by itself may not be a reliable factor in management efficiency, but it serves as the basis for the competencies that are necessary for success since professionalism is one of the components of competence. While "competence" is understood as an integrated characteristic of personality traits, the result of training a specialist to perform activities in certain areas (competencies). Competence, like competence, includes a competent (cognitive), motivational-value and emotional-volitional component. Competence is a situational category, as it is expressed in specific professional problem situations. Therefore, a certain level of emotional intelligence is required to teach specific competencies related to emotions. For example, the ability to understand how another person feels makes it possible to develop such competencies as the ability to influence other people, inspire them, etc. (Kuteeva, V.P., Yulina, G.N., Rabadanova, R.S., 2012).

Emotional intelligence allows you to regulate your behavior, realize the intended goal, and achieve the desired result. Realizing his goal, a person acts according to a plan that unfolds in the form of a series of thoughts and ideas and is realized through movements of a particular strength, speed, scope, consistency, accuracy. When performing movements, individual actions and mental operations associated with thinking about what, how and in what order should be done, concentration, intense attention to the process of activity appears. At the same time, a person experiences certain emotions: anxiety and displeasure due to obstacles and difficulties that have arisen, pleasure from the fulfillment of desires, labor recovery and fatigue, as well as joy from work itself (Kuteeva, VP, Yulina, GN, Rabadanova, RS, 2012).

According to a study carried out by the Kapjemini Research Institute in considering the question: "Will the competence of emotional intelligence become demanded and mandatory in the next 5 years? (that is, until 2024)"- 74\% (out of 750 respondents) managers and 58\% (out of 1,500 respondents) employees expressed their agreement with this issue. According to the respondents, this competence will be in demand:

- In less than a year: according to $5 \%$ of managers, $7 \%$ of employees;

- Within 1-3 years: according to $36 \%$ of managers, $24 \%$ of employees; 
- Within 3-5 years: according to $25 \%$ of managers, $17 \%$ of employees;

- More than 5 years later: according to $8 \%$ of managers, $9 \%$ of employees;

- $26 \%$ of managers and $42 \%$ voted that they cannot predict the time.

Thus, the development of emotional intelligence in employees and leaders of an organization can be a key factor in the success of an organization's development, as it covers the issues of self-management, self-motivation and interaction with other people, which contributes to an increase in overall productivity. Emotion management, recognition and analysis can increase the efficiency of decisions.

\subsection{Features of Employee Emotional Competence Formation}

Emotional intelligence is closely related to emotional competence. Emotional intelligence is the basis that is necessary for learning specific competencies related to emotions, that is, it is the ability, while emotional competence is the ability to be aware of one's own emotions, the emotions of another person, analyze them and manage them in order to choose the most effective behavior in a specific situation (Franzuzova, O.E.).

Thus, emotional intelligence is a set of competencies that manifest itself in how much a person: knows himself, controls himself, knows others and controls his relationships with others. Competence is manifested in a personal attitude to the corresponding competence and the subject of activity. Competence is the ability to influence an object; competence refers to the subject of activity, that is, the acquisition of personality, thanks to which a person can solve specific problems (Khutorskoy, A.V., 2006).

To effectively manage an organization, leaders need to develop emotional competence. Let's look at ways to form emotional competence. First of all, it is necessary to master emotional competencies: personal and social. They, in turn, are divided into four narrow categories: self-awareness, self-control, attunement to others (empathy), and relationship building (communication skills).

The development of a manager's emotional competence can take place in four steps:

1) Asking for feedback: this is due to the fact that emotional competence is associated with the ability to evaluate oneself from the outside and control one's actions;

2) Tracking the consequences, intentions and real impact: it is necessary to analyze how others feel from our actions, how they understand and interpret words and actions;

3) The ability to choose a model of behavior based on the situation, and not follow reflexes6 keeping pauses before the reaction, the leader learns to listen, as well as to control the possible negative impact of his emotions;

4) Development of empathy: develop the ability to take into account the needs of another person, assessing their own and others' plans and goals on their own and on the part of others.

These steps are related to the passage of the following stages of the development of emotional intelligence:

1) Awareness of the problem: awareness of their feelings and understanding of what they can be associated with;

2) Development of proactivity: that is, not to follow your reflexes, not to suppress emotions, but to control your attitude to the situation. In the development of proactivity, the leader is aware of the impact of external influence on his attitude and chooses a more appropriate behavior model;

3) Understanding motivation: defining your own incentives in the work. Determining the individuality of one's own motivation allows the manager to better understand the specific incentives of his employees, as well as how to influence them and his own;

4) Developing sensitivity, "empathy": understanding the mechanisms of reaction and reflexes of employees, understanding the sources of reactions and, as a result, implementing those actions that will be aimed at achieving goals without undesirable reaction of their colleagues;

5) Improving communication skills: identifying the most appropriate ways, time, place and means of communication, encouragement and punishment.

Thus, the stages of forming emotional intelligence are associated with its model. First of all, a person forms a mechanism for identifying his own emotions. Then there is an understanding of the sources and goals of emotions. Then there is an understanding of how to manage your emotions. By analogy, the manager is trained to identify the emotions of his employees, understand their incentives, goals and needs, and by improving his communication skills to manage their emotions and behavior, preventing his behavior from causing negative reactions. 
The development of emotional intelligence is influenced by the following internal and external factors: temperament, character, upbringing, the presence of affective disorders, social environment, etc. (Bobkova, N.G., 2016). Thus, emotional competence is the result of a person's life experience. Various events and behaviors of the environment form a person's special patterns of behavior, which are the sources of emotions. This phenomenon is explained by rational-emotive psychotherapy, which, according to A. Beck and A. Ellis, is based on the ABC scheme: A (activating event) - an event, B (beliefs) - beliefs, C (consequences) - consequences, namely emotions and appropriate behavior.

One of the manifestations of a low level of emotional intelligence is the manifestation of negative emotions, according to the above scheme, this is a consequence of a person's irrational beliefs. In order to translate irrational behavior into rational, the technique was supplemented with the letters: D (disputing) - disputing, E (effective new philosophy) - effective new philosophy (Pankratova, A.A., 2010).

This model is known as the proactive thinking model. Based on this model, the coach's work takes place. At the same time, the coach helps to identify the manifestations and incentives of the leader, directing him to possible options for changing his actions. Thus, for the development of emotional competence, the leader can use coaching services or use the self-coaching technique according to the above scheme.

The following stages are proposed as a model for the development of a proactive type of thinking:

1) Identification of situations in which the manifestation of reactivity occurs. Determining the cause of the situation that caused negative emotions.

2) Changing the way of thinking, which consists in changing the formats of the words and thoughts used. This will help develop positive attitudes.

3) Analysis of errors by identifying the cause.

4) Making commitments, that is, the implementation of actions, the consequences of which may or may not be known.

Thus, the formation of emotional competence in employees can be started by using various feedback tools. These include the 360-degree assessment, which includes assessing the actions of employees not only by the employee himself but also by his colleagues, managers and subordinates. This helps to expand the employee's understanding of their behavior, as well as the possibilities of changing the way they achieve their goals.

The formation of emotional competence can occur through training aimed at reflecting on one's own experience. The purpose of these training will be to capture and identify feelings and emotions that the employee experience, and to determine the root causes of these reactions. After that, the employee determines for himself additional signs of identifying this cause and chooses a new response model. In this case, the employee acquires the prerequisites for creating new patterns of behavior and new experiences.

However, the development of emotional competence involves social interaction. Based on this, team training should be organized that are related to managing emotions, as well as understanding the emotions of other people. The necessary tools for the development of the emotional competence of employees are also masterclasses and trainings, in which employees form an idea of the nature of emotions, possible options for behavior, conducting simulations with various scenarios that differ in the degree of use of emotional intelligence in work with colleagues, managers and clients. ... It is necessary to conduct a presentation to familiarize myself with the following topics "stress management", "the influence of emotions on a person's life", "the development of authenticity", "the development of skills of self-understanding and self-control" (Rozhkova, N.A).

Conducting training, during which employees get to know each other through special games, learn to identify the emotions of another person and identify their emotions. To develop emotional competence, techniques from the practice of acting are used, when employees need to repeat a certain emotion, and other employees to define it. These training also includes trainings to develop a sense of trust among employees.

Thus, the main feature of the development of emotional competence is the acquisition of new experience in managing emotions, understanding the causes and sources, and changing one's patterns of behavior.

\section{Discussion}

Using the example of a hypermarket in Kazan, we will consider the mechanism of the formation of employees' emotional intelligence. The number of personnel in the surveyed company is 390 people. Of these, 203 people participated in the study, which was conducted from March 20, 2020. 
To develop an algorithm for the formation of the emotional intelligence of company employees, it is necessary to start with an assessment of the current level of emotional intelligence. For this, the questionnaire of D. V. Lyusin can be used. Results of a survey of employees of a hypermarket in Kazan:

- 85 people (42\%) have a higher than average level of emotional intelligence;

- 34 people (17\%) have an average level of emotional intelligence;

- 84 people $(41 \%)$ have a level of emotional intelligence below average.

It should be noted that this questionnaire does not imply the use of a mechanism for a deeper and more comprehensive study of the level of emotional intelligence. Therefore, we have chosen the method of R. Bar-On as a mechanism, in which five main spheres of competence are presented, identified with five components of emotional intelligence (table 2).

Table 2. Emotional intelligence - R. Bar-On's model

\begin{tabular}{ll}
\hline Sphere name & Sphere components \\
\hline Intrapersonal sphere & - assertiveness \\
& - emotional self-analysis \\
& - self-respect \\
& - self-actualization \\
\hline The sphere of interpersonal relations & - empathy \\
& - social responsibility \\
& - interpersonal relationships \\
\hline The sphere of Adaptability & - Problem Solving \\
& - assessment of reality \\
\hline Stress Management sphere & - flexibility \\
\hline The sphere of general mood & - tolerance to stress \\
& - impulsivity control \\
\hline
\end{tabular}

Source: self made.

This model, as one of the mechanisms for identifying the level of emotional intelligence, allows research among employees and a more detailed study of the level of their emotional competence and the psychological climate within the team.

First of all, it is necessary to start with the intrapersonal sphere - each employee, the head of the company must clearly understand his emotional component - be able to adequately assess his emotional state, not depend on the assessment of his actions by others, that is, have a high level of assertiveness, regularly conduct emotional introspection in order to timely identify aspects that hinder effective and conflict-free cooperation with colleagues.

Next, the employee needs to build effective benevolent relationships with his colleagues - he must have empathy, that is, be able to provide moral support to the person in need, experience his emotional state with him, but at the same time not lose the clarity of understanding his personality.

An employee must understand that the level of his emotional competence and how well he is able to control his emotions constitute his social responsibility to colleagues - he must not show aggression towards others (colleagues and clients), must remain diplomatic and open in communication.

When a problem arises, the manager must constructively assess it, identify the causes of the occurrence and the consequences that may affect subordinates, customers and the company as a whole. The leader should carry out these actions with a minimum manifestation of emotions - without aggression, excitement, panic.

Flexibility is a good quality for any employee and manager. It shows how rationally and most faithfully, a person adapts to changes in the external environment. For example, when a global pandemic was announced in March 2020, 
retailers had to mobilize all of their employees to quickly restructure hypermarkets to meet changing conditions and customer needs. Flexibility became one of the decisive factors, thanks to which the management made the necessary decisions in the shortest possible time: issuing protective equipment to employees and customers of the hypermarket, the company did everything possible to ensure that the presence on the territory of the hypermarket was safe, relying on the observation of customer behavior and compliance with the prescribed state norms, based on this, making competent decisions.

One of the qualities of professionalism is stress resistance. In conditions of self-isolation, company employees found it difficult to cope with general unrest in society. Many employees had a fear of contracting the COVID-19 virus themselves or being a carrier for their family and acquaintances, so some employees considered it prudent to take leave to be removed from their duties and minimize the risk of infection. However, most of the hypermarket employees remained steadfast and did not succumb to general unrest, but continued to carry out their work under the clear guidance of their superiors, while taking all precautions. After the pandemic was announced, many hypermarket employees were skeptical about this information, did not believe in the existence of the COVID-19 virus. Some of the employees still believed in the reliability of the information, which provoked an increase in fear and uncertainty about complete safety at work. The managers of the hypermarket promptly took measures to monitor and protect the health of their staff, assuring employees that they were safe in the store and that they were in full control of the situation.

According to the results of our study, $7 \%$ of all employees of the hypermarket in Kazan, after talking with the management, still felt the emotion of fear of infection, so the management of the store had to send these employees on paid leave in order not to aggravate the situation within the team and not to raise panic.

The rest of the hypermarket employees, having full confidence in the actions of their management, took and implements all prescribed measures of conduct in the workplace, keeping calm. This demonstrates their high level of resilience to stress and the ability to quickly adapt to change, remain emotionally resilient, and continue to do their job effectively while helping the company and customers.

Negative skills do not affect a person in the best way, the pandemic only increased impulsiveness among employees. Therefore, the leaders of the hypermarket had to carefully work on this skills of their subordinates. Observing employees, the manager identified the most impulsive and invited him for a personal conversation in order to identify the reasons that provoked such a high level of impulsivity in the employee. With the help of a conversation, the head of a hypermarket could help his ward to understand the reasons for what was happening and find solutions with him to overcome this problem, direct his energy to achieve personal and organizational goals. It was during this difficult period that the correct suppression of impulsiveness helped the majority of employees make informed and correct decisions.

The role of the leader is to set and create a favorable atmosphere in the team, he needs to achieve maximum productivity and high-quality performance of the duties of his subordinates, not forgetting that when working with people it is important to understand and improve their morale, to strive to ensure that employees enjoy their work process, and in the conditions of general self-isolation, they remained calm and benevolent. The management of the hypermarket developed and adopted several measures that contributed to maintaining a positive attitude in the team:

- Active participation of employees in the discussion and joint decision-making with management to improve the methods of work of employees in the current situation;

- Holding meetings and meetings with colleagues to discuss the problems encountered;

- Holding collective meetings with informal topics for discussion, to defuse the situation;

- Full knowledge of the current state of the results of the hypermarket and the situation outside it.

These measures contributed to the preservation of a favorable environment in the hypermarket team and to better and more efficient joint decisions on the company's further actions in the context of self-isolation. If the store continues to operate on the principle of subsidiarity (when organizational problems are solved at the lowest or least centralized level), then it will very quickly come to improve its performance and increase the level of responsibility among its employees through the delegation of a number of powers and joint problem-solving.

After conducting a deep analysis of the level of emotional intelligence of employees of a hypermarket in Kazan, having examined it in detail in five areas of its manifestation, we assessed the level of emotional intelligence of employees on a ten-point scale to obtain the final result relative to the real level of emotional intelligence among employees of the hypermarket (Table 3). 
Table 3. Assessment of the level of emotional intelligence of employees of a hypermarket in Kazan by the components of the Bar-On model

\begin{tabular}{ll}
\hline Component & Score Max. - 10 points \\
\hline Controlling impulsivity & 7 \\
\hline Flexibility & 7 \\
\hline Conflict-free interpersonal relationships & 8 \\
\hline Assertiveness & 5 \\
\hline Expression ofempathy & 5 \\
\hline Stress tolerance & 6 \\
\hline Optimism & 8 \\
\hline Ability to solve problems & 8 \\
\hline
\end{tabular}

Source: self made.

Based on the assessments, it follows that the level of emotional intelligence among hypermarket employees is above average and it is necessary to develop it to improve personal and professional qualities. To do this, it is necessary to develop and implement a number of activities to identify, assess and increase the level of emotional intelligence among employees.

Consequently, the majority of hypermarket employees demonstrate above average levels of emotional intelligence in all five areas, which indicates a high-quality and benevolent interaction between the hypermarket manager and the subordinate. Hypermarket employees need to improve their emotional intelligence, and in a pandemic, they have every chance for this, since they need to maintain high-stress resistance, respond flexibly to changes, adapt to the needs of customers and maintain a festive mood in the team.

When using the Bar-On method as a mechanism for revealing the level of emotional intelligence of employees of a hypermarket in Kazan, it is necessary to use indicators to assess the level of emotional intelligence. Sector leaders should annually monitor the dynamics of the indicators of their subordinates, which they put down on the basis of annual analysis. This is especially true in a pandemic when the level of stress and panic among employees is at a high level, and managers, thanks to weekly monitoring, should promptly identify employees who have an increased level of negative emotions, be able to react quickly, provide support to the subordinate and jointly develop further action plan when working in a hypermarket.

Also, when using this method, it is recommended to apply the Performance review method, thanks to which the assessment of the level of emotional intelligence of employees will be more reliable, since when using this method, the level of emotional intelligence of an employee will be assessed not only by his manager, but also by his colleagues, and it will also be necessary his personal assessment of his emotions and actions. Upon completion of this method, the manager and the employee need to provide feedback so that the employee can ask questions of concern, briefly explain his assessment and receive comments from the manager, which, as a result, will contribute to more effective communication between the manager and the subordinate for more effective work in the future.

Human resources in a hypermarket need to assess emotional intelligence at the hiring stage. Since there are often cases, especially among young professionals, when a person suffers from an overabundance of emotions - fear of a new team or an unfulfilled task of a leader or a strong desire to show the best qualities can prevent you from concentrating on achieving the task. After hiring, each employee of the hypermarket goes through a training period, and it is important for a mentor-manager to identify the level of emotional intelligence of a potential subordinate before the training, so as not to spend a lot of time on psychological work with a person, but to immediately begin to familiarize himself with the new workplace and perform their job responsibilities.

Therefore, at the interview stage, it is necessary to assess the soft skills of a potential employee - his personal and communicative qualities, the level of responsibility, the ability to flexibly respond to changes, find compromises in conflict situations, and be able to communicate and negotiate.

A simple way to assess a potential employee for emotional intelligence is to include him in an artificially created situation, a game where he is asked to play certain roles with a certain set of rules and emotions. But when the situation begins to develop not according to plan and a person needs to adapt to the changed conditions, most often he begins to show his true emotions and then you can estimate his level of emotional intelligence as accurately as possible.

Also, at the recruiting stage, you can use the DISC test, developed by William Marston to study the emotions of people in terms of their behavior and interaction with the environment (Marketer.by). He identified 4 personality 
types, describing their characteristics, so after the potential employees pass this test, the accuracy of its results, showing how he will behave, and what actions and emotions he will not demonstrate, will be at least $90 \%$.

In the context of a pandemic, the hypermarket needs to increase the number of vacancies to work in the store, since some of the staff are on unscheduled vacations, the H.R. department needs to consider twice as many candidates for vacant positions. But for the effective selection of personnel, who, along with the necessary knowledge, must have high stress resistance and flexibility, the hypermarket should implement the AssessFirst application, which allows at the initial stage of employee selection, after passing the test in this application, to get their characteristics, which department employees hypermarket staff will be compared with previously set "ideal" parameters for the candidate and make the final decision on hiring a certain employee.

This application will allow, with an accuracy of at least $85 \%$, to identify all the necessary qualities of a potential employee of a hypermarket and will significantly reduce the time for selecting new personnel.

Employees of the personnel department need to periodically conduct trainings to increase the level of emotional intelligence among hypermarket employees, for this purpose, using the above methods, tests to identify the level of emotional intelligence of employees (Hall test, D. Goleman's test, D. Lyusin's questionnaire, etc.), which will reduce time to identify the characteristics of employees and develop methods to improve them. According to the results of our study, 84 employees of the hypermarket with a low level of emotional intelligence were identified, therefore, trainings must first of all be conducted for the selected employees, dividing them into 4 groups of 21 people in each and to each group send one of 4 employees of the personnel department for conducting training to increase the level of emotional intelligence. This proposal will improve the competencies of employees, as well as prepare them for a possible second epidemiological wave, so that in the autumn period the hypermarket management is not distracted by their training, but receives the result in the form of an increase in revenue indicators due to the more professional activities of its employees.

Also, the managers of the hypermarket should hold individual meetings with their wards to monitor their personal and professional growth, develop new missions and tasks, the responsibility for the implementation of which will lie entirely with the hypermarket employee, which will increase his motivation, level of responsibility and desire for a more productive learning process and development in the hypermarket. The emphasis on employee growth allows him to be more stress-resistant, to develop his abilities more effectively, to achieve more productive results of his actions as part of the implementation of his organizational tasks, as well as to rationally and objectively analyze his successes and failures in order to more successfully achieve the set goals.

The hypermarkets have large areas, 9300 sq. m., and often clients complain about the absence of consultants or their poor quality service. This issue is especially acute in the pre-holiday period (New Year, February 23, March 8). Due to the spread of COVID-19, an increase in the unemployment rate is projected until the first quarter of 2021. Consequently, the hypermarket will be able to provide additional jobs under a fixed-term contract for the period 12/10/2020 - 03/10/2021. By recruiting 16 people (based on the number of departments in the sales area), assessing their level of emotional intelligence in advance and selecting candidates with a high level or above average, training them to work in the sales area and familiarizing them with the assortment of goods, the hypermarket management will relieve the main staff of some of their responsibilities. thereby making the consultation process better and faster, which will increase customer loyalty to the store, thereby increasing sales and increasing profits.

Also, the growth orientation of a hypermarket employee allows him to adequately respond to criticism from colleagues and management, since in personal development, the employee analyzes the comments made to him and applies them in the course of his work to improve the results (Duek, K. Flexible consciousness, 2016).

The head of the hypermarket needs to constantly maintain feedback with his subordinates in order to identify the difficulties that have arisen in time, direct the employee's actions in the right direction, be a support, mentor for him and create a trusting relationship.

Also, in the course of training on the development and increase of the level of emotional intelligence among hypermarket employees, it is necessary to use testing to determine the type of employee's temperament. There are no ideal pure types, but each person has a predominant type, and its correct definition will allow the manager to make decisions faster and more correctly in relation to the actions of his subordinate, will allow to quickly build interpersonal relationships and communication methods, identify negative emotions and experiences of the employee in time, and to work them out as correctly as possible together with the employee.

For this, a five-factor personality questionnaire by R. McCrae and P. Costa should be used, which helps to determine the personality type by 5 factors:

- Extrovert or introvert;

- Attachment or isolation;

- Self-control or impulsivity; 
- Emotional instability or emotional stability;

- Expressiveness or practicality.

Thus, based on the conducted research, it is possible to formulate a list of measures to develop the emotional intelligence of employees.

1) Using the Performance Rewiew method for a better assessment of the level of emotional intelligence of workers (using the Bar-On model)

2) Installing the AssessFirst application for faster and better selection of candidates in the recruiting process

3) Conducting theoretical and practical trainings for managers and employees with a low level of emotional intelligence

4) Ensuring a continuous focus on the development of employees by involving them in the process of developing and making management decisions

5) Maintain a positive attitude in the team, which allows you to increase the level of stress resistance, be flexible to new changes in the environment, calmly control the situation and, together with management, develop new methods to improve the company's work.

\section{Conclusions}

Nowadays, unprecedently, human intelligence and "soft skills" are getting widespread in management activities. Soft skills are crucial to generate effective communication and interactions among employees and managers. Because of the capability of managing emotions, the staff is blessed with self-motivation, and effective management to cope with challenging situations and work stress. As a result, the overall efficiency of the staff will be remarkably increased.

Moreover, for the effective management of employees, another factor is highlighted - competence management, including the complex of emotional intelligence competencies.

Different measures to the definition of emotional intelligence permitted us to identify the following general parameters: awareness and control of our emotions, perception, and control of the emotions of others. Thus, due to the ability to manage emotions, the employee has the capacity of self-motivation, effective management of adverse situations, work with stress, as well as increase productivity and efficiency.

Accordingly, understanding the emotions of employees enables the company to assess its actions and correct them if needed, to effect conditions that will meet the needs of the staff in return for fulfilling the needs of the organization.

While considering the features of the formation of the emotional competence of employees, we figured out that emotional intelligence should be developed, mainly by managers. To this end, they brought a specific algorithm that promotes the development of emotional competence.

Emotional competence is the result of a person's life experience, and therefore several factors can contribute to creating difficulties in the growth of emotional competence.

We have considered options for analyzing the existing emotional competence, as well as measures for its development, which confirms the possibility that managers are affecting this factor.

\section{Acknowledgements}

The work is performed according to the Russian Government Program of Competitive Growth of Kazan Federal University.

\section{References}

About the assessfirst application. (2019). Assessfirst. Retrieved from https://www.assessfirst.com/ru/features

Andreeva, I. N. (2009). Social and emotional intelligence: from processes to measurements. Emotional intelligence as a factor of self-actualization, 5, 20-29.

Anokhin, P. K. (1984). Emotions. Psychology of Emotions, 288, 23-175.

Bereznyak, G. A., Martynov, Y. U. I., \& Salikov, Y. U. A. (2016). On some problems of managing a modern enterprise and ways to solve them, problems of regional economy. Bulletin, 4, 24-28. Retrieved from http://www.lerc.ru/?part=bulletin\&art=4\&page $=20$

Bobkova, N. G. (2016). Emotional intelligence as the key competence of the modern manager. Business Education in $\begin{array}{lllll}\text { Knowledge } & \text { Economics, } & \text { 2(4), } & \text { Retrieved } & \text { from }\end{array}$ https://cyberleninka.ru/article/n/emotsionalnyy-intellekt-kak-klyuchevaya-kompetentsiya-sovremennogo-mened zhera 


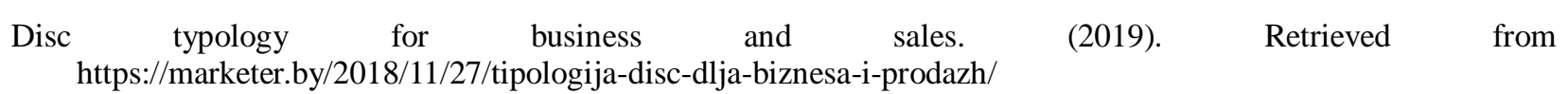

Duek, K. (2016). Flexible consciousnessю. Moscow: publishing house "mann, ivanov and ferber".

Emotional Intelligence in Today's Business. (2020). Business Review, 15.

Franzuzova, O. E. (n.d.). Emotional personality competence as a subject of study. Tambov state university. Retrieved from

http://www.tsutmb.ru/nayk/nauchnyie_meropriyatiya/int_konf/vseross/professionalno_lichnostnoe_razvitie_pre podavatelya_i_studenta_tradiczii,_problemyi,_perspektivyi2/sekcziya_2/emoczionalnaya_kompetentnost_lichn osti_kak_predmet_issledovaniya

Goldberg, C. (1991). Psychoanal, and psychother, Intelligence. Why Hamlet Could not Love, 9(1).

Goleman, D. (1988). The new york times sex roles reign powerful as ever in the emotions.

Interview with nassim taleb. (2020). $R b c, 8$.

Izard, K. A. (2000). Psychology of emotions. Spb: publishing house "peter".

Khutorskoy, A. V. (2006). Technology of design of key and subject competencies. Electronic journal eidos. Retrieved from http://www.eidos.ru/yournal/2006/0505.htm

Korolev, V. I. (2017). Quality of enterprise management: problems, ways to increase. Management Sciences, 1, 69-74. Retrieved https://cyberleninka.ru/article/n/kachestvo-upravleniya-predpriyatiem-problemy-puti-povysheniya

Kuteeva, V. P., Yulina, G. N., \& Rabadanova, R. S. (2012). Emotional intelligence as the basis for success in professional activities. Domestic and Foreign Pedagogy, 3(6), 59-65. Retrieved from https://cyberleninka.ru/article/n/emotsionalnyy-intellekt-kak-osnova-uspeshnosti-v-professionalnoy-deyatelnosti

Mckrai, R., \& Costa, P. (2015). Five-factor personal questionnaire. Psychology of a happy life. Retrieved from https://psycabi.net/testy/388-test-bolshaya-pyaterka-pyatifaktornyj-lichnostnyj-oprosnik-r-makkrae-p-kosta-met odika-diagnostiki-lichnostnykh-faktorov-temperamenta-i-kharaktera-5pfq

Naseri, T., \& Moradi, M. A. (2016). Emotional Intelligence and its Impact on Market Management. Journal of Management and Accounting Studies, 4(03), 63-66.

Novukupova, I. N., \& Mehdiyev, S. Z. (2016). Assessment of quality and efficiency of enterprise and personnel management. Bulletin of Eurasian Science, 1(32), 10-27. Retrieved from https://cyberleninka.ru/article/n/otsenka-kachestva-i-effektivnosti-upravleniya-predpriyatiem-i-personalom

Pankratova, A. A. (2010). Emotional intelligence: examples of the formation program. Psychological Research: Electronic Scientific Journal, 1(9). Retrieved from http://psystudy.ru

Proactive and reactive thinking, behavior and management. (n.d.). Retrieved from https://o-sebe.com/proaktivnoe-i-reaktivnoe-myishlenie-povedenie-i-upravlenie/\#i-7

Rogozhin, S. V., \& Rogozhina, T. V. (2002). Theory of organization. Moscow: Exam Publishing House.

Rozhkova, N. A. (2018). Emotional intelligence training program. Retrieved from https://imc72.ru/content/07082018/18.pdf

The bar-on model. (2016). Emotional intelligence. Retrieved from

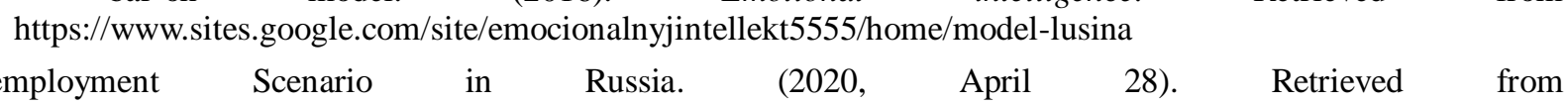
https://www.rbc.ru/society/28/04/2020/5ea87a179a794752f55d0511

Vekker, L. M. (1998). Psyche and reality: unified theory business education in the economics of knowledge of mental processes. Moscow: ast.

\section{Copyrights}

Copyright for this article is retained by the author(s), with first publication rights granted to the journal.

This is an open-access article distributed under the terms and conditions of the Creative Commons Attribution license (http://creativecommons.org/licenses/by/4.0/). 